\title{
FABRIKASI SEL SURYA DENGAN MENGGUNAKAN BUAH SENDUDUK (MELASTOMA MALABATHRICUM) SEBAGAI SENSITIZER DAN PEMBUATAN NANOMATERIAL TIO2 MENGGUNAKAN TEKNIK SOL-GEL
}

\author{
Hubertus Ngaderman, Ego Srivajawaty S, Yulia Fitri
}

Fisika, MIPA, Universitas Cenderawasih, Waena, Jayapura, 99351, Indonesia Universitas Cenderawasih, Waena, Jayapura, 99351, Indonesia

e-mail:ngadermanh@gmail.com

\section{ABSTRACT}

[Computation and modeling] The current solar cell technology is a technology developed by a process that is cheaper and easier in manufacturing. The solar cells sensitized by a dye below abbreviated writing that the DSSC is often also called Grätzel cells or whether the writing in Indonesian to be Sel Surya Berbasis Pewarna Tersensitisasi (SSPT).

DSSC is a potential candidate in as a third generation of solar cells (coming soon) because it does not require a material with a high degree of purity so that a low-cost production process. Dye used as a sensitizer can be either synthetic or natural. Metal-based organic dye complex ruthenium using synthetic (it is expensive), but it contains heavy metals that harm the environment. To reduce the cost of DSSC develops organic based on material sensitizer. DSSC using the same principles for the process of photosynthesis that behave as a chlorophyll dye that absorbs light and produces carrier.

The effectiveness of DSSC is no doubt that reaching more than $10 \%$ but with using this expensive type which is ruthenium complex metal-based organic. It is necessary to study massive research, a material awareness survey that has good performance, environmental costs. In this study will be carried out using DSSC senduduk fruit dye (Melastoma malabathricum) manufacturing and oxide semiconductors are nano materials (nanocrystals) $\mathrm{TiO}_{2}$ anatase gradually the solvotermal techniques.

Keywords: DSSC, dye, fruits senduduk, $\mathrm{TiO}_{2}$

\section{PENDAHULUAN}

Cadangan energi utama berupa minyak dan gas bumi di seluruh dunia termasuk di Indonesia semakin menipis. Sel surya sebagai suatu piranti yang berguna untuk mengkonversi cahaya matahari menjadi listrik adalah merupakan salah satu jawaban dari masalah penyediaan energi yang baru dan terbarukan di masa depan. Sel surya anorganik mempunyai efiiensi yang tinggi (Umeno et al, 1997) tetapi pengembangan membutuhkan investasi besar dengan fabrikasi yang sulit. Beberapa tahun terakhir telah dikembangkan sel surya dengan bahan organik. Beberapa yang dikenal adalah sel surya organik (SSO) dan DSSC. SSO dan DSSC mempunyai potensi sebagai piranti pengkonversi energi yang lebih murah dan mudah dalam fabrikasinya. Selain itu, rekayasaan hingga level molekuler dan sintesis bahan semikonduktor organik juga tidak terbatas, bahkan dapat diekstraksi dari tumbuhtumbuhan yang dapat dibudidayakan (Singh et al, 2006).
Pengembangan SSO makin pesat karena dipicu oleh keberhasilan pengembangan divais LED organik (OLED) yang sudah memasuki tahap komersial. SSO lapisan tipis terdiri dari beberapa jenis antara lain adalah SSO bulk (Monestier et al, 2007) dan SSO heterojunction (Yakimov, 2002) sedangkan DSSC hanyalah satu jenis tetapi material dye, semikonduktor oksida dan elektrolit yang bisa bervariasi. Riset ini terfokus pada DSSC dengan menggunakan dye buah senduduk (Melastoma Malabathricum) dan semikonduktor oksidanya adalah nanomaterial (nanokristal) $\mathrm{TiO}_{2}$ berfase anatase dan rutile serta elektrolitnya adalah iodine $\left(I^{-}\right)$dan triiodide $\left(I_{3}{ }^{-}\right)$.

DSSC nanokristal merupakan Sel Surya generasi ketiga (mendatang) hal ini dikarenakan ia tidak memerlukan material dengan tingkat kemurnian tinggi sehingga biaya proses produksi yang rendah. Dye yang digunakan sebagai sensitizer dapat berupa sintetik maupun alami. Dye sintetik menggunakan organik logam berbasis ruthenium komplek (jenis ini 
mahal), selain itu berpengaruh buruk pada lingkungan. Untuk mengurangi biaya dikembangkan DSSC berbasis organik pada material sensitizernya. DSSC menggunakan prinsip yang sama dengan proses fotosintesis yaitu dye bertingkah laku seperti klorofil yang menyerap cahaya dan memproduksi pembawa (carrier). Efisiensi untuk DSSC tidak diragukan lagi yaitu mencapai di atas $10 \%$ tetapi dengan menggunakan jenis yang mahal itu yaitu organik logam berbasis ruthenium komplek. Maka diperlukan penelitian yang secara besarbesaran mencari, menginvestigasikan material sensitizer yang mempunyai performansi baik, murah dan aman bagi lingkungan.

Tujuan penelitian ini adalah membuat (fabrikasi) DSSC dengan menggunakan dye buah senduduk dan semikonduktor oksidanya adalah nanomaterial (nanokristal) $\mathrm{TiO}_{2}$ dengan teknik deposisi spin coating. Menentukan efisiensi berdasarkan eksperimen dan membuat pola karakteristik $I-V$ dan efisiensi juga berdasarkan modeling.

\section{METODOLOGI PENELITIAN}

Bahan-bahan yang digunakan dalam penelitian ini meliputi kaca TCO (Transparent Conductive Oxide), serbuk $\mathrm{TiO}_{2}$ (MERCK), triton, etanol $75 \%$, aquades, buah senduduk. Peralatan yang digunakan adalah multi meter digital, magnetic stirrer, hotplate, penjepit kertas, penjepit buaya, beaker glass $25 \mathrm{ml}$, pensil karbon, pipet tetes, spatula, batang gelas (glasstirringrod), timbangan digital, tisu, spin coaster SCS 6800 dan Spektrofotometer UVVis Genesys.

Bahan dasar dari layer oksida ini adalah semikonduktor $\mathrm{TiO}_{2}$ (Merck) 3,5 gram yang dicampurkan dengan etanol sebanyak $15 \mathrm{ml}$ di dalam beaker glass. Campuran ini kemudian diletakkan di atas stirrrerplate yang kemudian diaduk rata dengan menggunakan magnetic stirrer. Untuk membuat larutan dye ekstrak buah senduduk dilakukan dengan menyiapkan buah senduduk secukupnya dan diletakkan kedalam gelas baker setelah itu digerus dengan menggunakan mortar. Setelah itu masukkan etanol 75\% kedalam gelas beaker sebanyak 15 $\mathrm{ml}$ setelah itu diamkan selama 2 jam lalu kita pisahkan dye dengan butiran-butiran halus dengan menggunakan spin coaster SCS 6800 selama 2 menit.

Pengujian ini dilakukan dengan menggunakan alat Spektrofotometer UV-Vis Genesys yang bertujuan agar peneliti mengetahui daya absorbansi dari buah senduduk. Untuk pendeposisian pasta $\mathrm{TiO}_{2}$ dan karbon dilakukan dengan menyiapkan dua kaca TCO yang telah dipotong berbentuk persegi dengan ukuran panjang $2 \mathrm{~cm}$ dal lebar $2 \mathrm{~cm}$ yang telah dicuci bersih dengan menggunakan etanol yang selanjutnya dibersihkan dengan tisu lalu dikeringkan dengan hairdryer. Setelah kering taruh kaca TCO diatas tempat bersih dengan posisi sisi konduktif menghadap keatas lalu beri lakban putih disetiap sisi sekitar $0,5 \mathrm{~cm}$ agar pasta yang kita teteskan tidak mengenai seluruh permukaan kaca. Setelah pastanya dioleskan pada kaca secara merata lalu kita tunggu selama 5 menit agar pastanya benarbenar kering setelah pastanya menempel lalu kita panaskan dengan menggunakan alat hotplate selama 15 menit dengan suhu $30^{\circ} \mathrm{C}$ untuk kaca TCO yang kedua kita lapiskan karbon dengan menggunakan pensil karbon.

\section{HASIL DAN PEMBAHASAN}

Hasil penelitian fabrikasi DSSC dye buah dan nanokristal $\mathrm{TiO}_{2}$ dengan teknik deposisi spin coating adalah ditampilkan pada Gambar. Kurva tersebut lewat melalui empat kuadran oleh karena itu daya tersebut bisa diekstrak dari divais ini. Kurva $I-V$ secara umum dihadirkan oleh Gambar 1 dan invers dari Karakteristik $I-V$ pada Gambar 2. Intensitas awal $23 \mathrm{~W} / \mathrm{m}^{2}$, luasan area $2,38 \mathrm{~cm}^{2}$, daya awal 0,05474watt, kuat arus maksimum $\left(I_{\max }\right)$ $0,056 \mathrm{~mA}$, tegangan maksimum $\left(V_{\max }\right)$ $88,6 \mathrm{mV}$, daya maksimum $\left(P_{\max }\right) 0,0049616$ watt, arus short circuit $\left(I_{s c}\right) 0,098 \mathrm{~mA}$ dan tegangan open circuit $\left(V_{o c}\right) 143,1 \mathrm{mV}$ dan Fill Factor 0,3537985. Efisiensi yang diperoleh $9,06 \%$. 


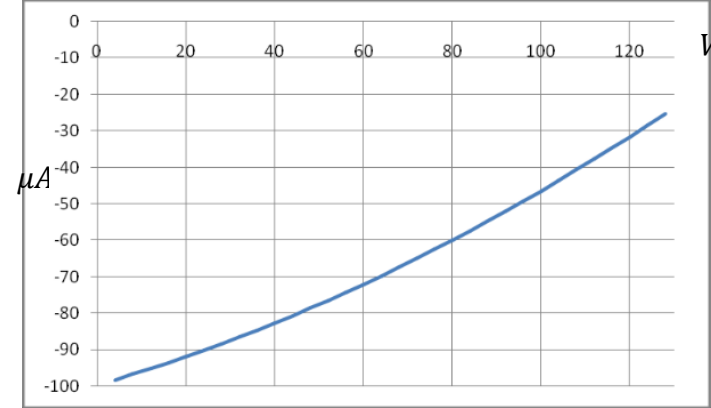

Gambar 1 Karakteristik $I-V$.

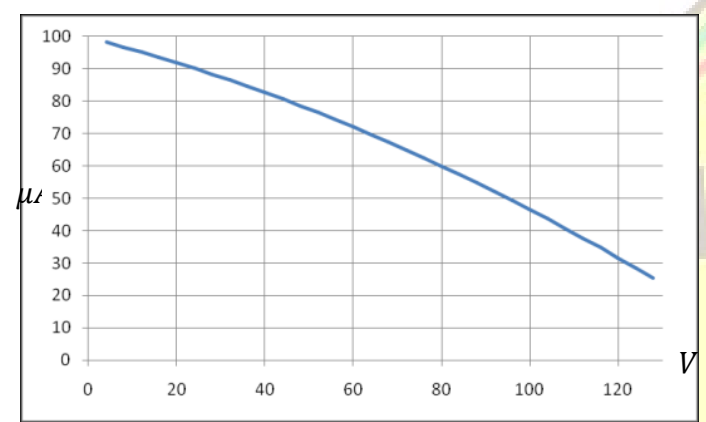

Gambar 2 Karakteristik $I-V$ kurva

Pencocokkan karakteristik $I-V$ dengan Metode Least Square. Dari kurva karakteristik ini maka dibuat persamaan.

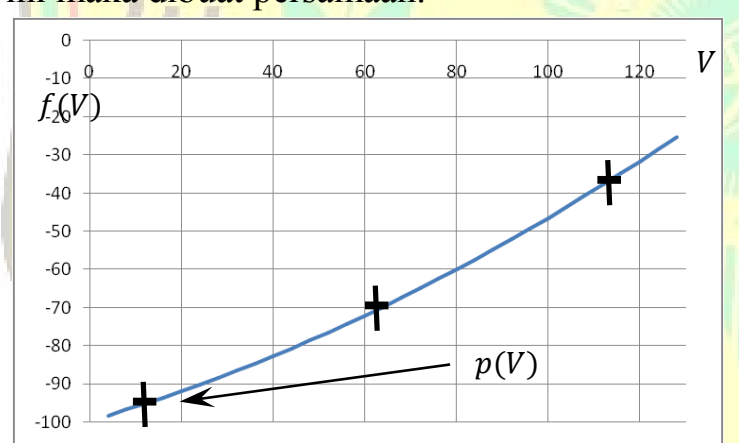

Gambar 4.3 Fungsi polinomial dari

Keterangan kurva di atas adalah $f\left(V_{i}\right)$ mewakili data; $i=1, \ldots, N$. Pada grafik diatas jumlah $\mathrm{N}$ nya adalah 3 data. Polinomial $p(V)$ merupakan fungsi yang dicocokkan terhadap data $f\left(V_{i}\right)$. Dalam perumusan sederhana tertulis:

$\mathrm{p}(\mathrm{V})=\sum_{\mathrm{j}=0}^{\mathrm{m}} \mathrm{a}_{\mathrm{j}} \mathrm{V}^{\mathrm{j}}$

Fungsi $p(V)$ ditentukan dengan mencari nilai $a_{j}$, dimana $j$ memiliki nilai $0, \ldots, m$.

Untuk mencari nilai $a_{j}$ maka kita mengambil nilai dari $f(V)$ dan $V$, ditulis:

$$
\begin{gathered}
\sum_{j=0}^{m}\left(\sum_{i=1}^{N} V_{i}^{j+k}\right) a_{j} \\
=\sum_{i=1}^{N} f\left(V_{i}\right) V_{i}^{k} \quad(k \\
=0, \ldots, m)
\end{gathered}
$$

Sesudah itu didefinisikan nilai $v_{k j}$ dan $i_{k}$ sebagai berikut:

$$
\begin{array}{r}
v_{k j} \equiv \sum_{i=1}^{N} V_{i}^{j+k} \quad i_{k} \\
=\sum_{i=1}^{N} f\left(V_{i}\right) V_{i}^{k}
\end{array}
$$
linear:

maka diperoleh sebuah sistem persamaan

$$
\begin{aligned}
\sum_{j=0}^{m} v_{k j} a_{j} & =i_{k} \\
& =0, \ldots, m)
\end{aligned}
$$

Solusi dibawa dalam bentuk matriks untuk penyelesaiannya.

$$
(V)[A]=[I] \text { atau } V A=I
$$

Jadi, $a_{j}$ diperoleh sebagai solusi persamaan linear $V A=I$. Tiga data $f(x)$ yaitu $f(0,0046)=0,000098 \quad, \quad f(0,0065)=$ 0,000069 dan $f(0,0127)=0,000026$. Fungsi $p(x)$ dapat melukiskan data itu, $p(x)$ bukan linear. Jadi dicoba fungsi kuadratik:

$$
\begin{gathered}
p(V) \\
=a_{0}+a_{1} V+a_{2} V^{2}
\end{gathered}
$$

Sistem persamaan linear untuk mencari $a_{j}$ :

Jadi,

$$
\begin{gathered}
p(V)=0,02812 V^{2}+0,00141 V \\
-0,000106(6)
\end{gathered}
$$

Fungsi kurva karakteristik $I-V$ invers

$$
p(V)=0,000106-0,00141 \mathrm{~V}
$$

$$
-0,02812 V^{2}(7)
$$
karakteristik arus tegangan $I-V$ real dari DSSC ini.

Mengikuti pers (3.3)

$$
\mathrm{I}=\mathrm{I}_{\mathrm{S}} \mathrm{e}^{\frac{\mathrm{qV} T}{\mathrm{kT}}}+\mathrm{I}_{\mathrm{s}}-\mathrm{I}_{\mathrm{L}}
$$

sama dengan $I_{s c} 0,098 \mathrm{~mA}$ atau $98 \mu \mathrm{A}$. Sehingga 


$$
\begin{aligned}
p(V)= & \left(0,02812 V^{2}+0,00141 V\right. \\
& -0,000158) \\
& -0,0000098
\end{aligned}
$$

dengan mengurutkan sesuai dengan urutan kuadratik maka

$$
\begin{aligned}
" \quad p(V)= & -(0,000158-0,00141 V \\
& \left.-0,02812 V^{\wedge} 2\right) " \\
- & 0,0000098
\end{aligned}
$$

Menggunakan deret binomial yang diambil dari Mathematical Methods In The Physical Science Boas M L, 1983 maka fungsi kurva karakteristik diatas dapat ditulis:

$$
p(V)=-10^{-9} \cdot a\left(1+V+\frac{1}{2} V^{2}\right)
$$

$a$ adalah nilai yang harus bersesuaian dengan

$$
=e^{q / k T}
$$

Jika mengambil hanya suku pertama dari pers (9) maka

$$
\begin{aligned}
& 10^{-9} \cdot a \\
& =1,58 \cdot 10^{-4} \\
& \text { dan } \\
& a \\
& =1,58 \cdot 10^{5} \\
& \text { oleh karena itu } \\
& \frac{q}{k T} \\
& =\ln 1,58.10^{5} \\
& \text { atau } \\
& \frac{q}{k T}=1,61 V^{-1} \\
& =1,61 \mathrm{volt}^{-1}
\end{aligned}
$$

Jika $k T$ memiliki nilai $0,025 \mathrm{eV}$ maka $q$ untuk SS ini adalah $4,025 \cdot 10^{-21} C . I_{S}$ adalah arus saturasi $I_{S}$ memiliki nilai $1 n A$ atau $10^{-6} \mathrm{~mA}$. Karena $I_{s}$ nilainya terlalu kecil maka dapat diabaikan dalam pers (4.10). $I_{L}$ sama dengan $I_{S c}$ bernilai $9,8 \cdot 10^{-5} \mathrm{~A}$.

\section{KESIMPULAN}

Dye sintetik mahal, untuk mengurangi biaya dikembangkan DSSC berbasis organik pada material sensitizernya dengan menggunakan dye buah senduduk. Fabrikasi DSSC dengan menggunakan dye buah gowok dan semikonduktor $\mathrm{TiO}_{2}$ dengan teknik deposisi spin coating. Menentukan efisiensi berdasarkan eksperimen dengan cara membuat pola karakteristik $I-V$. Bisa juga menentukan efisiensi berdasarkan modeling.

Hasil penelitian fabrikasi DSSC dye buah dan nanokristal $\mathrm{TiO}_{2}$ dengan teknik deposisi spin coating. Intensitas awal $23 \mathrm{~W} / \mathrm{m}^{2}$, daya awal 0,05474watt, kuat arus maksimum $\left(I_{\max }\right)$ $0,056 \mathrm{~mA}$, tegangan maksimum $\left(V_{\max }\right)$ $88,6 \mathrm{mV}$, daya maksimum $\left(P_{\max }\right) 0,0049616$ watt, arus short circuit $\left(I_{s c}\right) 0,098 \mathrm{~mA}$ dan tegangan open circuit $\left(V_{o c}\right) 143,1 \mathrm{mV}$ dan Fill Factor 0,3537985. Efisiensi yang diperoleh $9,06 \%$. Variabel dan parameter diatas diperoleh berdasarkan eksperimen dan diperoleh parameter mikroskopik yang paling khas yaitu muatan carrier (pembawa). Parameter ini tidak bisa diperoleh lewat eksperimen hanya bisa diperoleh melalui komputasi dan pemodelan.

Perlu dilakukan penelitian lanjutan dengan menggunakan metode least square untuk mendapatkan parameter internal yaitu muatan carrier dengan ketepatan perhitungan yang tinggi. Penambahan lebih dari 3 data polinomial $p(V)$ adalah salah satu cara. Peneliti menghitung besar nilai $k T(0,025 \mathrm{eV})$ berdasarkan perkalian dari $k$ (konstanta Bolztman) dan $T$ (suhu kamar) dimana nilai mereka adalah parameter-parameter ketetapan yang sudah baku. $q$ untuk pemodelan ini adalah $4,025 \cdot 10^{-21} C$, oleh karena itu perlu diadakan kajian yang berulang-ulang sehingga didapatkan besar nilai $q$ yang tidak lain adalah muatan carrier yang lebih valid.

\section{DAFTAR PUSTAKA}

Boas M L, 1983. Mathematical Methods In The Physical Science. John Wiley and Sons, De Paul University.

Cullity, B. D. 2001. Elements of X-Ray Diffraction $3^{\text {th }}$ edition. Addison-Wesley Publishing Company.

DeVries.P.L. A First Course in Computational Physics. John Wiley and Sons.

Durst R W, Wrolstad R E, 2005. Characterization and Measurement of Anthocyanins by UV-visible 
Spectroscopy. Handbook of analytical food chemistry. NewYork: John Wiley \& Sons.

Gretzel, Michael, Smestad, 1998. Demonstrating electeron Transfer and nanotechnology A Natural Dye Sensitized nanocrystalline Energy Converter. Journal of Chemical Education.

Jogiyanto H.M, 1998. Dasar-dasar Pemrograman Pascal. Andi Offset,Yogyakarta.

Kumara M, Prajitno G, 2012. Studi Awal Fabrikasi Dye Sensitized Solar Cell (DSSC) Dengan Menggunakan Ekstraksi Daun Bayam (Amaranthus Hybridus) Sebagai Dye Sensitizer Dengan Variasi Jarak Sumber Cahaya Pada DSSC. Institut Teknologi Sepuluh Nopember.

Nasori, 2012. Pengembangan dan fabrikasi Dye Sensitized Solar Cell berbasis jahe Merah Dengan metode deposisi Spin Coating dan Docot Blade. Thesis, Jurusan Fisika Fakultas Matematika dan Ilmu Pengetahuan Alam, ITS Surabaya.
Oregan, Gratzel, 1991. A low-Cost, High Efficiency Solar Cell Based On Dye Sensitized Colloidal $\mathrm{TiO}_{2}$ Films. Nature Vol.353.

Puspita, Nurisma, 2012. Studi Awal Pembuatan Prototype Dye Sensitizer Solar Cell (DSSC) Menggunakan ekstraksi Rosella (Hibiscus Sabdariffa) Sebagai Dye Sensitizer Dengan variabel Luas permukaan lapisan $\mathrm{TiO}_{2}$. ITS Surabaya.

Smestad, Greg P, 1998. Education and Solar Conversion: Demonstrating Electron Transfer. Solar Energy Materials and Solar Cells.

Smestad, Greg P, Gratzel, 1998. Demonstrating Electron and Nanotechnology: A Natural Dye-Sensitized Nanocrystalline Energy Converter. Journal of Chemical Education.

Sze S.M., 2003. Physics of Semiconductor Devices 2nd edition, John Wiley and Sons. 